\title{
Adrenocortical suppression in multiply injured patients: a complication of etomidate treatment
}

\author{
I W FELLOW', M D BASTOW, A J BYRNE, S P ALLISON
}

\begin{abstract}
Three patients admitted to the intensive care unit after multiple injury were observed to suffer episodes of adrenocortical insufficiency suggested by clinical manifestations and confirmed by appropriately low cortisol concentrations. This prompted a prospective study of pituitary-adrenocortical function in six multiply injured patients, three of whom showed evidence of adrenocortical suppression. The only factor common to the six patients with abnormally low adrenocortical function was an association between periods of adrenocortical suppression and intravenous infusion of etomidate; when the drug was stopped adrenocortical function was restored, and renewed administration of the drug caused further inhibition. Etomidate infusions lasting only six hours were found to cause low, flat responses to short tetracosactrin tests and grossly raised plasma concentrations of adrenocorticotrophic hormone, suggesting direct suppression of the adrenal cortex. Median plasma cortisol concentrations measured at 0900 were significantly lower and median plasma concentrations of adrenocorticotrophic hormone measured at 0900 were significantly higher in the three patients studied prospectively who were receiving etomidate infusions compared with the three patients who did not receive etomidate $(p=0.05)$.
\end{abstract}

\section{Introduction}

Acute adrenocortical suppression in multiply injured patients is reportedly rare. ${ }^{1}$ We were surprised, therefore, to observe three multiply injured patients with this complication in the intensive care unit, and so began a prospective study of pituitary-

University Hospital, Queen's Medical Centre, Nottingham NG7 2UH I W FELLOWS, BA, MRCP, honorary medical registrar

M D BASTOW, BSC, MRCP, medical registrar

A J BYRNE, MB, FFARCS, consultant anaesthetist

S P ALLISON, MD, FRCP, consultant physician

Correspondence to: $\operatorname{Dr} I \mathbb{W}$ Fellows. adrenocortical function in multiply injured patients admitted to the unit. This study was terminated after reports indicated increased mortality in patients treated with etomidate infusions ${ }^{2}$ and incriminated adrenocortical suppression as a possible aetiological factor. This prompted us to examine retrospectively our records of etomidate infusion and to correlate this treatment with changes in adrenocortical function in the patients studied.

\section{Patients and methods}

During 1982 three multiply injured patients in our intensive care unit developed clinical features of Addisonian crisis associated with abnormally low plasma cortisol concentrations. We therefore studied prospectively six further patients admitted after traumatic injury, three of whom received etomidate. Plasma concentrations of adrenocorticotrophic hormone and cortisol were determined daily at 0900 and tests were performed using a stimulus of $0.25 \mathrm{mg}$ tetracosactrin (Synacthen) intravenously with measurement of plasma cortisol concentration at 30 and 60 minutes. In the six patients studied prospectively the median plasma concentrations of adrenocorticotrophic hormone and cortisol measured at 0900 in the three patients who received etomidate were compared with those in the three patients who did not (Mann-Whitney $U$ test; $p=0.05$ was taken as denoting a significant difference). Injury severity scores of the patients were determined by the method of Baker et al. ${ }^{3}$

TABLE I-Clinical and biochemical details of three patients with adrenocortical suppression found retrospectively to be associated with etomidate infusions. Values of plasma cortisol concentration are basal values and those measured 30 and 60 minutes after intravenous administration of $0.25 \mathrm{mg}$ tetracosactrin

\begin{tabular}{|c|c|c|c|c|c|c|}
\hline $\begin{array}{l}\text { Case } \\
\text { No }\end{array}$ & $\underset{\text { (years) }}{\text { Age }}$ & $\begin{array}{c}\text { Injury } \\
\text { severity } \\
\text { score }\end{array}$ & $\begin{array}{l}\text { No of } \\
\text { days } \\
\text { after } \\
\text { trauma }\end{array}$ & $\begin{array}{c}\text { Rate of } \\
\text { infusion of } \\
\text { etomidate } \\
(\mathrm{mg} / \mathrm{h})\end{array}$ & $\begin{array}{c}\text { Plasma } \\
\text { cortisol } \\
(\mathrm{nmol} / \mathrm{l})\end{array}$ & $\begin{array}{l}\text { Addisonian } \\
\text { features }\end{array}$ \\
\hline 1 & 50 & 41 & $\left\{\begin{array}{r}7 \\
20\end{array}\right.$ & $\begin{array}{r}60 \\
0\end{array}$ & $\begin{array}{c}100 \\
340,590,620\end{array}$ & Hypotension \\
\hline 2 & 24 & 25 & $\left\{\begin{array}{l}12 \\
73\end{array}\right.$ & $\begin{array}{r}80 \\
0\end{array}$ & $\begin{array}{c}80 \\
320,760,900\end{array}$ & $\begin{array}{c}\text { Hyperkalaemia, } \\
\text { hyponatraemia }\end{array}$ \\
\hline 3 & 29 & 25 & $\left\{\begin{array}{l}14 \\
20 \\
23 \\
57 \\
64\end{array}\right.$ & $\begin{array}{r}50 \\
65 \\
0 \\
0 \\
0\end{array}$ & $\begin{array}{c}230 \\
60,90,100 \\
200,180,610 \\
610,640,710 \\
350,740,830\end{array}$ & $\begin{array}{l}\text { Hypotension, } \\
\text { pigmentation }\end{array}$ \\
\hline
\end{tabular}

Conversion: SI to traditional units-Cortisol: $1 \mathrm{nmol} / 1 \approx 0.036 \mu \mathrm{g} / 100 \mathrm{ml}$. 
Case 4

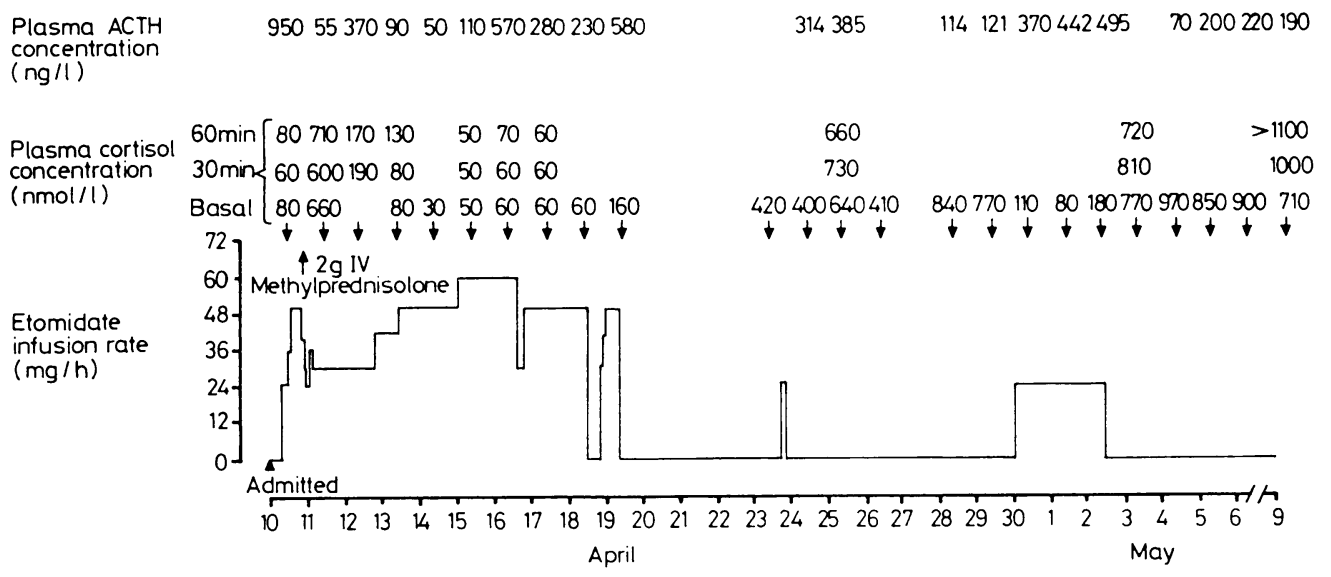

\section{Case 5}

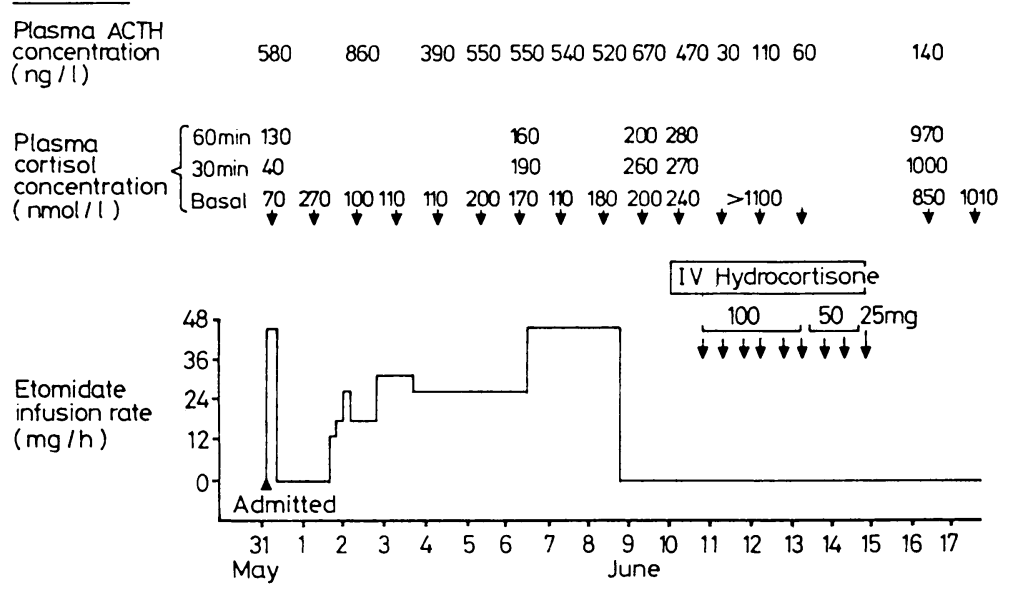

\section{Case 6}

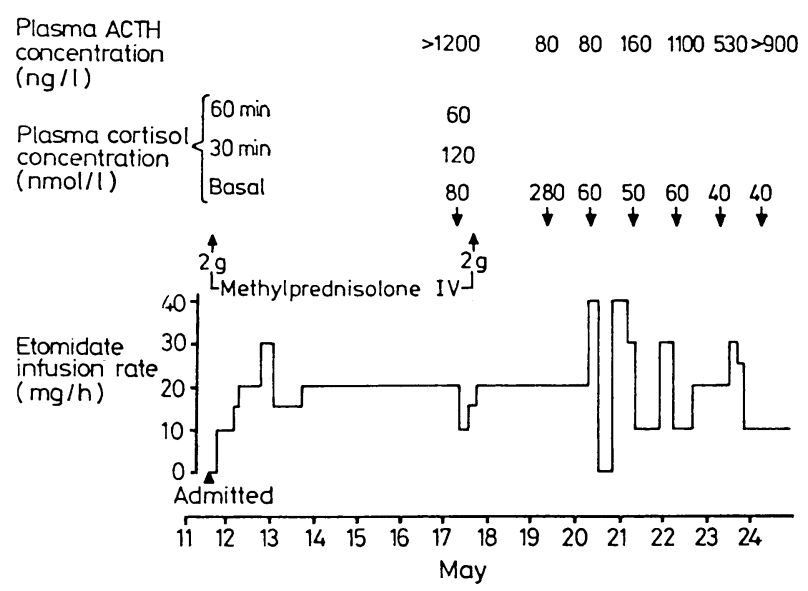

Serial plasma concentrations of adrenocorticotrophic hormone (ACTH) and of cortisol measured immediately before and 30 and 60 minutes after administration of $0.25 \mathrm{mg}$ tetracosactrin intravenously in cases 4,5 , and $6 . \mathrm{IV}=$ Intravenously.

Conversion: SI to traditional units-Cortisol: $1 \mathrm{nmol} / 1 \approx 0.036 \mu \mathrm{g} / 100 \mathrm{ml}$.

In patients receiving etomidate the infusion rate was altered according to individual requirements, using a modified Glasgow coma scale. ${ }^{4}$ Some patients required additional muscle relaxants to ensure efficient ventilation, and in these the minimum rate of infusion of etomidate to ensure sedation was given, based on the previous requirement.

Plasma adrenocorticotrophic hormone concentration was measured by immunoassay (kit IM66, Amersham International) (between batch coefficients of variation were $10.8 \%$ at a mean concentration of $50 \mathrm{ng} / 1$ and $17 \%$ at a mean concentration of $900 \mathrm{ng} / 1$; normal range $0-100$ ng/l). Plasma cortisol concentration was estimated by immunoassay of ${ }^{125}$ I labelled cortisol using solid phase antisera raised against cortisol30-carboxymethyloxime; between batch coefficients of variation were $13 \%$ at a mean concentration of $100 \mathrm{nmol} / 1(3.6 \mu \mathrm{g} / 100 \mathrm{ml})$ and $9 \%$ at a mean concentration of $800 \mathrm{nmol} / 1(29 \mu \mathrm{g} / 100 \mathrm{ml})$ (normal concentration at $0900>250 \mathrm{nmol} / \mathrm{l}(>9 \cdot 1 \mu \mathrm{g} / 100 \mathrm{ml})$ ).

\section{Results}

\section{PATIENTS STUDIED RETROSPECTIVELY}

The three patients in this group showed low plasma cortisol concentrations in the presence of clinical features suggesting the possibility of an Addisonian crisis; all three patients received infusions of etomidate concurrently with these episodes (table I). Two patients (cases 1 and 2) received intravenous methylprednisolone $2-4 \mathrm{~g}$ on the day of admission. The remaining patient (case 3 ) did not receive methylprednisolone, but intravenous administration of hydrocortisone $100 \mathrm{mg}$ after the short tetracosactrin test on day 20 led to a prompt increase in arterial blood pressure (systolic arterial blood pressure increased from 95 to $120 \mathrm{~mm} \mathrm{Hg}$ within an hour of injection of hydrocortisone) and reversal of oliguria. In all three patients adrenocortical function was restored after the etomidate infusion was stopped.

\section{PATIENTS STUDIED PROSPECTIVELY}

Of the six patients studied prospectively, only three received etomidate infusions during their admission. Two patients (cases 4 and 5 (figure)) had abnormally low plasma cortisol concentrations and grossly raised plasma adrenocorticotrophic hormone concentrations on the day of admission within six hours after receiving etomidate infusions. In case 4 adrenocortical function recovered after the etomidate infusion was stopped; further administration of etomidate on day 20 of admission led to prompt lowering of the plasma cortisol concentration with a reciprocal increase in the plasma concentration of adrenocorticotrophic hormone. When etomidate was stopped on day 22 adrenocortical function was restored within 24 hours. In case 5 there was similar recovery of adrenocortical function after the etomidate infusion was stopped. In case 4 transient hypotension occurred immediately before the administration of methylprednisolone, but otherwise there was no clinical evidence of an Addisonian crisis; in case 5 there was no clinical evidence of adrenocortical insufficiency, although hydrocortisone was administered prophylactically for five days after etomidate was stopped. In case 6 (figure) the patient also showed low plasma cortisol concentrations, a flat response to the short tetracosactrin test, and a raised plasma concentration of adrenocorticotrophic hormone while receiving etomidate; these abnormalities were transiently relieved by methylprednisolone but recurred before death on the 14th day of admission.

The three patients not given etomidate (cases $7,8,9$ ) showed normal adrenocortical function apart from on one occasion in case 10 , 
when at 0900,60 hours after administration of methylprednisolone $2 \mathrm{~g}$ intravenously, the plasma cortisol concentration was $100 \mathrm{nmol} / 1$ $(3.6 \mu \mathrm{g} / 100 \mathrm{ml})$ and plasma adrenocorticotrophic hormone concentration was $110 \mathrm{ng} / \mathrm{l} ; 24$ hours later the response to a short tetracosactrin test was normal $(260 \mathrm{nmol} / \mathrm{l}(9.4 \mu \mathrm{g} / 100 \mathrm{ml})$ increasing to $860 \mathrm{nmol} / 1$ $(31.0 \mu \mathrm{g} / 100 \mathrm{ml})$ one hour after administration of tetracosactrin). This solitary low plasma cortisol concentration was attributed to the effect of methylprednisolone in suppressing the hypothalamic-pituitary axis. ${ }^{5}$

Median plasma cortisol concentrations at 0900 were significantly lower in the three patients receiving etomidate than in the three patients not receiving it (table II; $p=0 \cdot 05$ ). Similarly, median plasma concentrations of adrenocorticotrophic hormone were significantly higher in those patients receiving etomidate than in those not (table II; $p=0 \cdot 05$ ). To exclude the effect of methylprednisolone in suppressing the hypothalamic-pituitary axis ${ }^{4}$ we analysed these data excluding the results of assays performed within three days after administration of methylprednisolone (table III); the disparity in the plasma concentrations of cortisol and adrenocorticotrophic hormone between the two groups of patients persisted $(p=0.05)$.

TABLE II-Clinical and biochemical details of six patients studied prospectively, three of whom received etomidate (cases 4, 5, and 6). Plasma cortisol and adrenocorticotrophic hormone concentrations are expressed as medians (and ranges)

\begin{tabular}{|c|c|c|c|c|c|}
\hline $\begin{array}{l}\text { Case } \\
\text { No }\end{array}$ & $\underset{\text { (years) }}{\text { Age }}$ & $\begin{array}{l}\text { Injury } \\
\text { severity } \\
\text { score }\end{array}$ & $\begin{array}{l}\text { No of } \\
\text { days } \\
\text { after } \\
\text { trauma }\end{array}$ & $\begin{array}{l}\text { Plasma cortisol } \\
\text { at } 0900(\mathrm{nmol} / \mathrm{l})\end{array}$ & $\begin{array}{c}\text { Plasma } \\
\text { adrenocorticotrophic } \\
\text { hormone at } \\
0900(\mathrm{ng} / \mathrm{l})\end{array}$ \\
\hline \multicolumn{6}{|c|}{ Patients receiving etomidate } \\
\hline $\begin{array}{l}4 \\
5 \\
6\end{array}$ & $\begin{array}{l}55 \\
17 \\
70\end{array}$ & $\begin{array}{l}38 \\
26 \\
45\end{array}$ & $\begin{array}{l}1-23 \\
1-9 \\
7-14\end{array}$ & $\begin{array}{r}80(30-660) \\
110(70-200) \\
60(40-280)\end{array}$ & $\begin{array}{l}370(50-950) \\
550(390-860) \\
530(80->1200)\end{array}$ \\
\hline \multicolumn{6}{|c|}{ Patients not recetving etomidate } \\
\hline $\begin{array}{l}7 \\
8 \\
9\end{array}$ & $\begin{array}{l}70 \\
44 \\
17\end{array}$ & $\begin{array}{l}13 \\
29 \\
41\end{array}$ & $\begin{array}{l}1-6 \\
1-14 \\
1-4\end{array}$ & $\begin{array}{c}>1100(730->1100) \\
1000(400-1080) \\
360(100->1100)\end{array}$ & $\begin{array}{c}95(36-180) \\
170(60->800) \\
110(100-120)\end{array}$ \\
\hline
\end{tabular}

Conversion: SI to traditional units-Cortisol: $1 \mathrm{nmol} / 1 \approx 0.036 \mu \mathrm{g} / 100 \mathrm{ml}$.

TABLE III-Plasma cortisol and adrenocorticotrophic hormone concentrations (median's (and ranges)) in six patients studied prospectively, values obtained within three days after administration of methylprednisolone $2 \mathrm{~g}$ intravenously (in cases 4, 6, and 9) being excluded

\begin{tabular}{ccc}
\hline Case No & Plasma cortisol at $0900(\mathrm{nmol} / \mathrm{l})$ & $\begin{array}{c}\text { Plasma adrenocorticotrophic } \\
\text { hormone at 0900 (ng/1) }\end{array}$ \\
\hline \multicolumn{4}{c}{ Patients receiving etomidate } \\
4 & $60(30-180)$ & $370(50-950)$ \\
5 & $110(70-200)$ & $550(390-860)$ \\
6 & $50(40-80)$ & $900(160->1200)$ \\
& Patients not receiving etomidate \\
7 & $1100(730-1100)$ & $95(36-180)$ \\
8 & $1000(400-1080)$ & $170(60->800)$ \\
9 & $380(260-500)$ & $115(110-120)$ \\
\hline
\end{tabular}

Conversion: SI to traditional units-Cortisol: $1 \mathrm{nmol} / 1 \approx 0.036 \mu \mathrm{g} / 100 \mathrm{ml}$.

\section{EFFECTS OF OTHER DRUGS}

All nine patients studied received many other drugs during their admission, particularly antibiotics, opiates, benzodiazepines, histamine $\mathrm{H}_{2}$ receptor antagonists, and beta adrenoceptor agonists, but etomidate was the only agent whose administration was related invariably to suppression of the plasma cortisol concentration and an increase in the plasma adrenocorticotrophic hormone concentration. All other drugs that were prescribed during the episodes of adrenocortical suppression were also administered during periods of normal pituitaryadrenocortical function, either in the same patient or in patients who never showed abnormalities of the pituitary-adrenocortical axis.

\section{Discussion}

These results indicate that adrenocortical suppression may occur in a group of patients previously suggested not to be at risk. ${ }^{1}$ The original three patients in whom adrenocortical suppression was observed were found on review to have received etomidate infusions that were related temporally to the episodes of adrenocortical suppression, and in one case prompt reversal of symptomatic hypotension and oliguria was seen after intravenous injection of hydrocortisone $100 \mathrm{mg}$. Normal adrenocortical function was restored after the etomidate infusion was stopped in these three patients.

Among the patients studied prospectively only those who were receiving etomidate infusions suffered adrenocortical suppression, while those sedated with opiates and benzodiazepines showed plasma cortisol concentrations appropriate for multiply injured patients. ${ }^{6}$ Plasma cortisol concentrations recovered when etomidate was stopped and were suppressed further when it was started again. The suppression of plasma glucocorticoid concentrations occurred within six hours of the start of etomidate infusion in two patients; this time course was comparable with the acute effect of etomidate injection into rodents ${ }^{7}$ and suggested that the original three patients may have suffered adrenocortical suppression for several days before developing symptoms of hypotension or hyponatraemia and hyperkalaemia. The concurrence of a low, flat response to the short tetracosactrin test and grossly raised plasma concentrations of adrenocorticotrophic hormone strongly suggested a direct effect of etomidate in suppressing either synthesis or secretion of cortisol by the adrenal gland, rather than a central effect as suggested by its action mimicking that of $\gamma$-aminobutyric acid. ${ }^{7}$

In this group of patients maintenance of arterial blood pressure was not critically dependent on normal adrenocortical function, which may explain previous reports of the stability of cardiovascular function when etomidate is used as an induction agent in anaesthesia. ${ }^{8}$ Other mechanisms that maintain arterial blood pressure, such as angiotensin II, may be important in adrenocortical suppression. ${ }^{9}$

Only one of the patients in this study died, and the study was terminated on receipt of information from the Committee on Safety of Medicines on reports of increased mortality in injured patients receiving long term infusion of etomidate ${ }^{2}$; thus the data are insufficient to show any effect on mortality.

This effect of etomidate merits further study as it raises the possibility that similar compounds might have therapeutic potential in controlling secretion of steroids.

Plasma ACTH assays were performed by Dr A M J Woolfson and Mr C Selby, department of clinical chemistry, City Hospital, Nottingham. Plasma cortisol assays were performed by Dr G Walker, Dr D Hill, and Mr C Henson, department of clinical chemistry, University Hospital, Nottingham. We thank Miss M McLean for typing the manuscript.

\section{References}

${ }^{1}$ Sainsbury JRC, Stoddart JC, Watson MJ. Plasma cortisol levels. A comparison between sick patients and volunteers given intravenous cortisol. Anaesthesia 1976; 36:16-21.

${ }^{2}$ Ledingham IMcA, Watt I. Influence of sedation on mortality in critically ill multiple trauma patients. Lancet $1983 ; \mathrm{i}: 1270$.

${ }^{3}$ Baker SP, O'Neill B, Haddon W, Long WB. The injury severity score: a method for describing patients with multiple injuries and evaluating emergency care $\mathcal{F}$ Trauma $1974 ; 14: 187-98$

4 Edbrooke DL, Newby DM, Mather SI, Dixon AM, Hebron BS. Safer sedation for ventilated patients. A new application for etomidate. Anaesthesia $1982 ; 37: 765-71$.

${ }^{5}$ Novak E, Stubbs SS, Seckman CE, Hearron MS. Effects of a single large intravenous dose of methylprednisolone sodium succinate. Clin Pharmacol Ther 1970;11:711-7.

${ }^{6}$ Stoner HB, Frayn KN, Barton RN, Threlfall CJ, Little RA. The relationships between plasma substrates and hormones and the severity of injury in 277 recently injured patients. Clin Sci 1979;56:563-73.

${ }^{7}$ Preziosi P, Vacca M. Etomidate and corticotrophic axis. Arch Int Pharmacodyn Ther 1982;256:308-10.

${ }^{8}$ Roberts JG. Intravenous anaesthetic agents. In: Prys-Roberts C, ed. The circulation in anaesthesia-applied physiology and pharmacology. Oxford: Blackwell Scientific, 1980:481-2.

${ }^{9}$ Bennett T, Gardiner SM. Effect of saralasin on blood pressure, after adrenalectomy, of rats with isolation-induced hypertension. $\mathrm{Br} \mathcal{F}$ Pharmacol 1983;79:251P.

(Accepted 5 October 1983) 